\title{
Interactions between an ascoglossan sea slug and its green algal host: branch loss and role of epiphytes
}

\author{
Cynthia D. Trowbridge*
}

Department of Zoology, Oregon State University, Hatfield Marine Science Center, Newport, Oregon 97365, USA

\begin{abstract}
On rocky intertidal shores in Oregon, USA, the ascoglossan (= sacoglossan) sea slug Placida dendritica A. \& H. consumed the green seaweed Codium fragile (Sur.) Har. but not the epiphytic red alga Ceramium codicola J. Ag. attached to C. fragile. Field studies conducted from 1986 to 1992 suggested that herbivore grazing negatively affected the seaweed. During spring and summer, P. dendritica attacked ca $70 \%$ of the large C. fragile (thalli $>10 \mathrm{~cm}$ ) at Boiler Bay, Oregon. Ascoglossans were most abundant on the axillary region of branches. Grazing by the herbivore weakened branches, resulting in branch loss. C. fragile thalli with the epiphyte $C$. codicola were attacked more frequently than those without epiphytes. In a 1 mo field experiment, $P$. dendritica settlement and survivorship were greater on thalli with $C$. codicola than on thalli with epiphytes experimentally clipped. Recently settled ascoglossan recruits associated with epiphyte cover more frequently than did larger ascoglossans. The sea slug-seaweed-epiphyte association represents an unusual form of herbivore-plant interaction in that (1) herbivores do not consume epiphytes but (2) epiphytes enhance herbivore attack of seaweed.
\end{abstract}

\section{INTRODUCTION}

The extent to which grazers partition their feeding between 2 types of potential foods - macrophytes and epiphytes - may result in fundamentally different herbivore-algal interactions. Some marine and freshwater herbivores (e.g. amphipods, crabs, snails, young fish, insects, oligochaetes) often selectively consume epiphytes, reducing epiphyte loads without directly affecting the macroalgal or seagrass host (Caine 1980, Brawley \& Adey 1981, Howard 1982, Robertson \& Mann 1982, Van Montfrans et al. 1982, Cattaneo 1983. Brönmark 1985, 1989, D'Antonio 1985, Brawley \& Fei 1987, Brostoff 1988, Coen 1988a, b, Mazzella \& Russo 1989, Duffy 1990, Dudley 1992). Thus, herbivory may have an indirect positive effect on macrophytes. Alternatively, some grazers ingest macrophytic and epiphytic tissue, though whether epiphytes are consumed

\footnotetext{
- Correspondence address: Leigh Marine Laboratory, University of Auckland, PO Box 349, Warkworth, New Zealand
}

intentionally or incidentally has not been fully explored (Nicotri 1977, 1980, Lobel \& Ogden 1981, Shacklock \& Croft 1981, Norton \& Benson 1983, Shacklock \& Doyle 1983, D'Antonio 1985, Duffy 1990). In both cases, herbivores typically have a negative direct effect on epiphytes, though dispersal of propagules or vegetative cells that survive herbivore digestion may benefit the algae (Buschmann \& Santelices 1987, Kitting 1989, Buschmann \& Bravo 1990).

In this study, a third type of herbivore-macrophyteepiphyte association is examined in which the grazer does not consume epiphytes at all. This type of interaction occurs (1) when a generalist or polyphagous herbivore avoids epiphytes or (2) when a stenophagous herbivore specializes on macrophytic hosts. The frequency with which the former situation occurs is not well known. In contrast, most of the ca 200 species of stenophagous ascoglossan sea slugs (Mollusca: Gastropoda: Opisthobranchia) selectively eat macroalgae though a few species consume diatoms or epiphytic red algae (Jensen 1980, 1981, Brandley 1984). When a herbivore does not consume epiphytes, a vari- 
ety of interactions may develop between taxa sharing a common algal host: epiphytes may facilitate herbivore attack, block herbivore access, or not influence the herbivore-seaweed association (positive, negative, and neutral direct effects, respectively). The intricacies of these types of herbivore-seaweed-epiphyte interactions have not been previously explored.

The focus of this study is the common temperate ascoglossan Placida dendritica A. \& H. which selectively consumes the green algae Codium and Bryopsis (Schmekel \& Portmann 1982, Trowbridge 1991a). The ascoglossan's association with Codium fragile (Sur.) Har. was examined because the alga typically has a substantial epiphyte load. C. fragile is a large (up to $41 \mathrm{~cm}$ tall), roughly dichotomously branching green alga that inhabits low intertidal and subtidal rocky shores in the NE Pacific (Abbott \& Hollenberg 1976, Scagel et al. 1986). The seaweed is a native species, genetically different (Goff et al. 1992) from the invading pest $C$. fragile subsp. tomentosoides found on most temperate shores. On the Oregon coast, the most common epiphyte on C. fragile is the perennial red alga Ceramium codicola J. Ag. that has an obligate association with Codium spp. (Scagel et al. 1986), forming coarse tufts $<5 \mathrm{~cm}$ on $C$. fragile (Abbott \& Hollenberg 1976).

This study addresses 2 specific questions about the herbivore-macrophyte-epiphyte association: (1) How do the ascoglossan sea slugs affect their macroalgal hosts? (2) Do epiphytes influence the herbivoreseaweed interaction?

\section{METHODS}

Coarse-scale patterns. Seaweed population: The population of Codium fragile (henceforth called Codium) examined in this study was a dense, low intertidal bed ca $500 \mathrm{~m}^{2}$ in area at Boiler Bay State Park $\left(44^{\circ} 50^{\prime} \mathrm{N}, 124^{\circ} 4^{\prime} \mathrm{W}\right.$ ) on the central coast of Oregon. In May 1992, two $15 \mathrm{~m}$ transect lines were placed within the low intertidal zone, parallel to the shoreline. In 25 quadrats (each $625 \mathrm{~cm}^{2}$ ) randomly placed along the transect lines, the following information was noted: (1) number of Codium thalli, (2) number and length of Codium axes or fronds, (3) presence and maximum length of epiphytes, and (4) presence of ascoglossans and/or their grazing damage.

Grazing effects: To evaluate the nature and implications of ascoglossan grazing damage, a belt transect
(15 m long, $0.25 \mathrm{~m}$ wide) was censused for Codium damaged by Placida dendritica (henceforth called Placida). The ascoglossan's suctorial feeding produces damage distinctly different from that of other grazers (Trowbridge 1992a). Codium thalli are composed of interwoven filaments that form an unpigmented medulla and a pigmented cortical region with siphonlike utricles. Placida punctures the utricles and sucks out chloroplasts and cytoplasm: the resulting damage is a region of collapsed utricles much paler than surrounding undamaged utricles (Fig, 1). Amphipods and isopods tend to shred the utricles whereas snails and chitons scrape the cortical surface of utricles (Trowbridge 1992 a, pers. obs.).

For the first 100 damaged thalli encountered, the most proximal location of Placida feeding damage was categorized (base, stipe, first axillary region, etc.) (Fig. 2). The amount of incipient tissue loss was estimated for 50 damaged thalli. Two lengths were measured for every thallus: total length of Codium and length from the most proximal point of damage to branch tips. The second value represented the amount of incipient tissue loss due to slug grazing, because Codium thalli abscise distally to points of grazing damage. Because of the dichotomous branching pattern of Codium, a branch lost from one side of the thallus would not necessarily result in a shortening of the entire thallus but would often represent a substantial loss of biomass.

To test whether Placida caused branch loss of Codium on the shore, 2 short-term field experiments were conducted in May 1989. In the first experiment, 12 undamaged thalli with few epiphytes were tagged. Treatments were randomly assigned: 0 or 10 large Placida added per thallus to a lower axillary region. After $12 \mathrm{~d}$, tagged thalli were examined and the nature of the damage categorized as algal tissue lost (branches or entire thallus) or not lost. The second experiment was similar with the following modifications: (1) 20 Placida in the addition treatment, (2) 33 thalli were tagged, and (3) tagged thalli were sampled after $2 \mathrm{~d}$. For both experiments, the frequency of algal tissue loss in the 2 treatments was compared using Fisher's exact tests.

Seaweed and epiphyte attributes: To test if Ceramium codicola (henceforth called Ceramium) directly enhanced Placida attack, epiphyte abundance was experimentally manipulated in situ. In April 1992, 50 thalli of Codium with epiphytes were randomly

Fig. 1 Placida dendritica (circled) on Codium fragile, in situ, in May 1992 at Boiler Bay, Oregon, USA. Areas of ascoglossan grazing damage are pale green regions, particularly at branch dichotomies. About $70 \%$ of $C$. fragile thalli exhibit this type of damage in spring and summer 


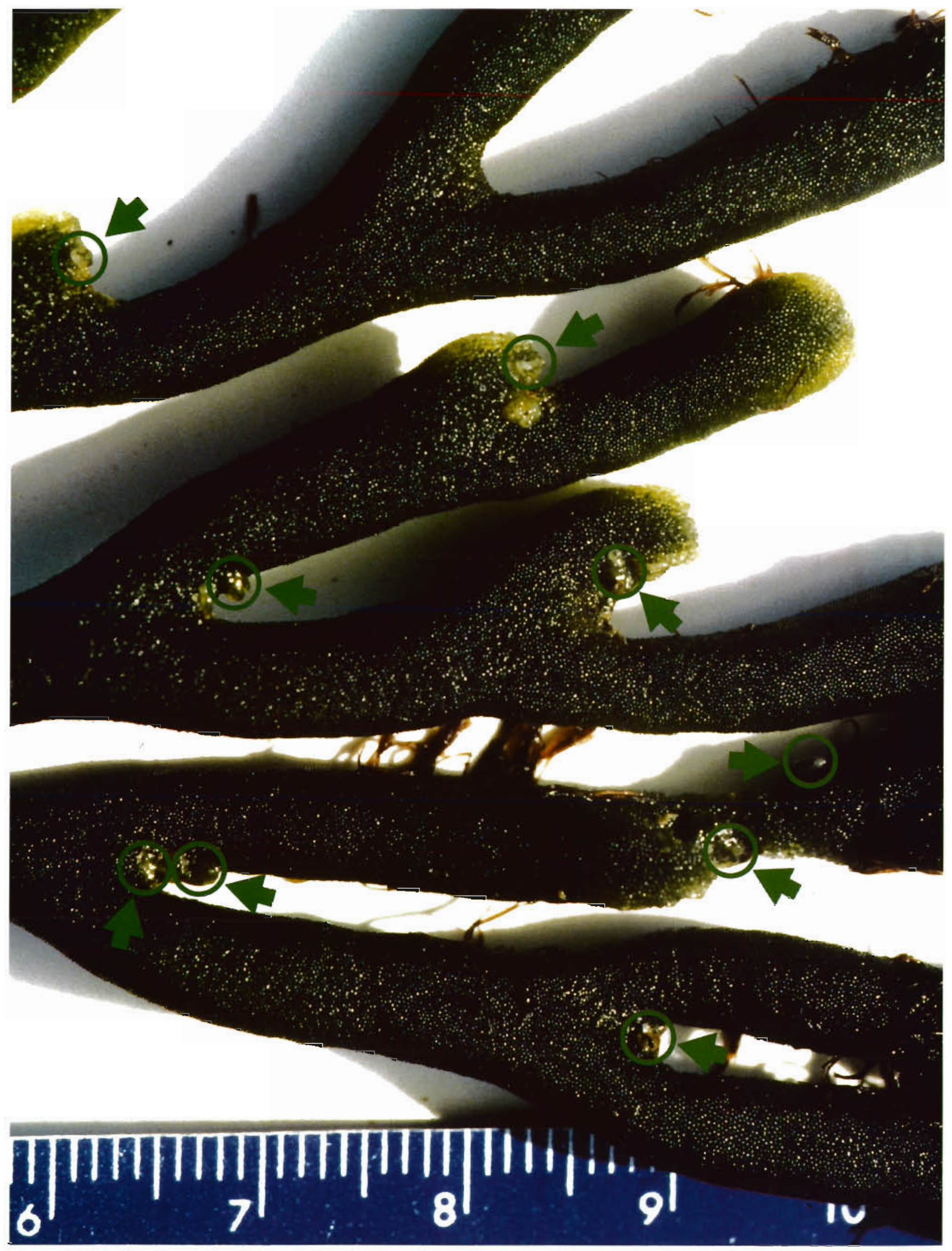




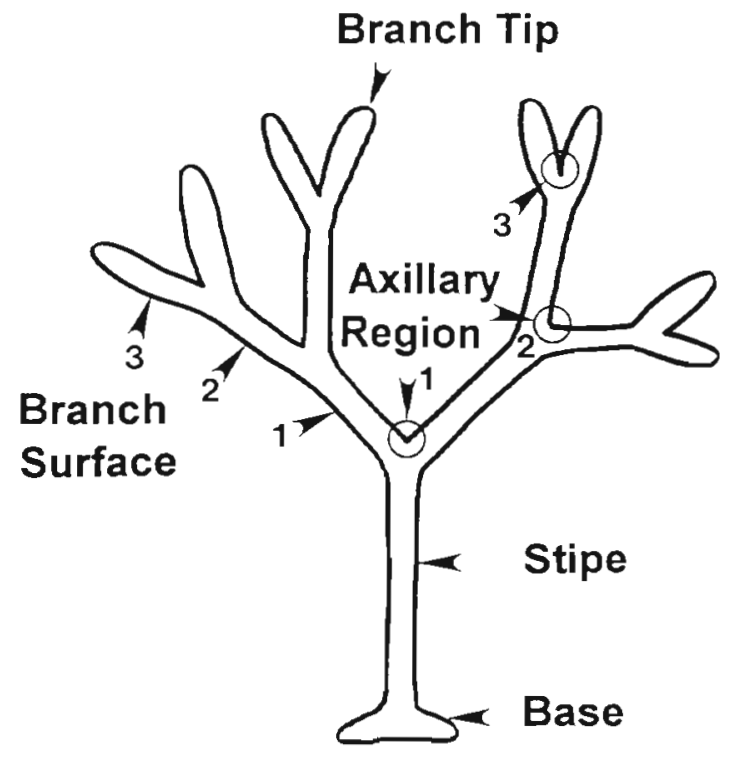

Fig 2. Schematic diagram of the green alga Codium fragile and terms used in text. For clarity, the illustrated thallus has only one axis or frond arising from the basal holdfast; most thalli have many such axes

selected and tagged. Ceramium was clipped from 25 thalli (epiphyte-reduction) and not from the other 25 thalli (control). The timing of this experiment was important: the experimental manipulation was conducted immediately prior to the seasonal appearance of Placida (Trowbridge 1992b) so slug recruitment during the experiment was not biased by between-plant variation in resident slugs and/or existing grazing damage.

After $1 \mathrm{mo}$, the remaining tagged Codium thalli were harvested (14 control and 17 experimental thalli). Codium and Ceramium lengths were measured, and the ascoglossans on each thallus were counted, using a dissecting microscope. Because of time constraints and unexpectedly high slug densities, counts were not made for 4 randomly selected thalli. To determine whether Placida abundance was lower in the epiphytereduction treatment than in the undisturbed control, a comparison of ascoglossan abundance (no. per thallus) was made, using a 1-tailed Student's $t$-test. Data were transformed (logarithm of counts) prior to analysis. Normality was checked using Lilliefor's test, and homogeneity of variances was checked using Bartiett's test. Two other assumptions were checked: that Codium size did not differ between treatments and that the experimental manipulation was effective. Between-treatment comparisons of wet mass and thallus length of Codium were made with 2-tailed Student's $t$-tests, and the maximum epiphyte length per thallus was compared between treatments with a 1 -tailed Mann-Whitney $U$-test.
Fine-scale patterns. Seaweed region: During spring and summer in 1987 and 1988, the pattern of microhabitat use by Placida on Codium was documented. Each month, 20 thalli were collected at $1 \mathrm{~m}$ intervals within the Codium bed at Boiler Bay and were examined under a dissecting microscope within $2 \mathrm{~h}$ of collection. To check whether Placida remained fairly sedentary during aerial exposure, the location of ascoglossans was visually determined immediately after the seaweed was exposed on an ebbing tide. Another confirmation that the sampling procedure produced little bias was that the location of ascoglossan grazing damage corroborated the observed location of Placida.

For each ascoglossan, 3 types of information were recorded. (1) Sea slugs were categorized as recruits $(<0.5 \mathrm{mg})$, juveniles $(0.5$ to $0.9 \mathrm{mg})$, small adults (1.0 to $3.0 \mathrm{mg}$ ), and large adults (>3 mg) (Trowbridge 1992b). (2) The sea slug's location was categorized as base, stipe, axillary region, branch surface, or branch tip (Fig. 2). For Placida on branch surfaces, it was noted whether the slugs were under Ceramium. (3) It was noted whether Placida occurred as a solitary individual or a group member closely associated with other conspecifics; $_{i}$ feeding aggregations of Placida create extensive damage to Codium spp. (Clark 1975, Trowbridge 1991b, 1992a).

Epiphytes: Macroalgae with epiphytes may be more attractive to herbivores than conspecific thalli without epiphytes (e.g. if epiphytism is related to stress). To determine whether Placida preferred epiphytized Codium, a laboratory experiment was conducted in August 1986. Five ascoglossans were placed in each of 28 plastic containers (0.5 l) with pairwise choices of Codium with and without Ceramium. After $2 d$, the location of all sea slugs was determined, and the extent of grazing damage was estimated as none (0), some (1), or extensive (2). Because choices were not statistically independent, feeding preferences and relative grazing damage were not compared statistically, but summary values are presented.

Although the feeding specificity of Placida has been well documented (Trowbridge 1991a, unpubl. data), at least 1 species of ascoglossan seasonally shifts its diet between Codium sp. and an epiphytic red alga (Brandley 1984). To test whether Placida would associate with or consume Ceramium, an experiment was conducted in July 1992. The epiphyte was gently removed intact from Codium at Boiler Bay. Small $(<5 \mathrm{~cm})$ Codium thalli and adult Placida were also collected and brought back to the laboratory. Ten slugs were placed in each $0.5 \mathrm{l}$ plastic container with fresh seawater and with either Codium or Ceramium ( $\mathrm{n}=9$ containers per algal species). Slugs on algae were counted 5 times during the $1 \mathrm{~d}$ experiment, and the percentage 
of Placida on Codium and Ceramium was calculated Placida was maintained for $1 \mathrm{wk}$, and observations were made to determine qualitatively if slugs gained or lost weight.

\section{RESULTS}

\section{Coarse-scale patterns}

Seaweed population

Codium was patchily distributed along the central coast of Oregon. At Boiler Bay, the alga was extremely sparse $\left(<1\right.$ thallus $\mathrm{m}^{-2}$ ) except for the low intertidal, wave-protected bed studied. In the Codium bed, the alga occurred in 12 of the 25 random quadrats examined. Mean Codium density was 17.3 thalli $(\mathrm{SD}=21.1$, $\mathrm{n}=25$ ) and 391.7 axes ( $\mathrm{SD}=546.4, \mathrm{n}=25$ ) per $\mathrm{m}^{2}$ of intertidal substratum. On average, each Codium thallus bore 26.3 axes or fronds $(S D=17.9, \mathrm{n}=27$ ) per basal holdfast.

Individual axes within and among thalli of Codium varied widely in length, epiphyte load, and ascoglossan attack. About $90 \%$ of the axes were $<8 \mathrm{~cm}$ in length (Fig. 3A) and had few, if any, epiphytes

\section{A. Codium}

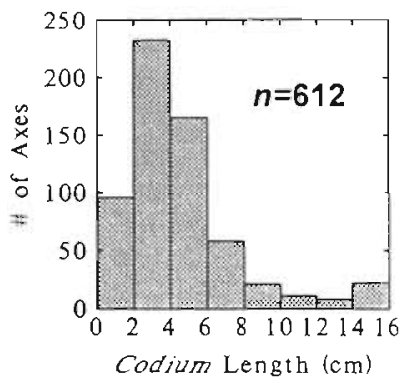

C. Ceramium

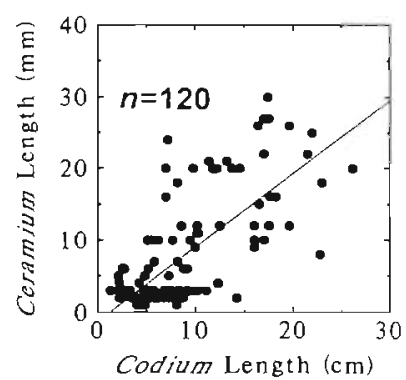

B. Ceramium

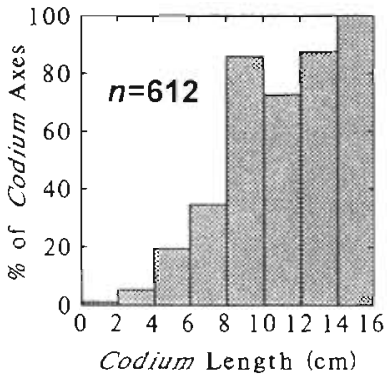

D. Placida

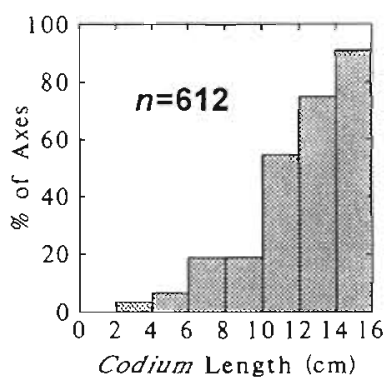

Fig. 3. (A) Size-frequency distribution of Codium fragile axes or fronds in May 1992 at Boiler Bay, Oregon. Size-specific occurrence of the (B, C) epiphyte Ceramium codicola and (D) herbivore Placida dendritica on $C$. fragile hosts. Data were based on 25 random quadrats (each $625 \mathrm{~cm}^{2}$ ). Sample sizes indicate number of $C$. fragile axes examined
(Fig. 3B). Large axes (>10 cm) were usually covered with a moderate to lush epiphyte load, and epiphyte length increased significantly with increased Codium length (Spearman rank correlation, $r_{\mathrm{s}}=0.673, \mathrm{p}<$ $0.001, n=120$; Fig. 3C). Visible signs of ascoglossan attack were primarily on the large Codium with Ceramium (Fig 3D). Although large axes represented a small fraction of the total number, they composed the majority of Codium biomass.

\section{Grazing effects}

Although Placida occurred simultaneously on many parts of each algal host (Fig. 1), the most proximal site of severe damage would result in the highest amount of algal tissue loss. Of 100 damaged Codium thalli examined, 72 were damaged in the first or second axillary region (Fig. 4). Furthermore, in $>80 \%$ of the cases of damage, Placida was clearly associated with the damage. If these weakened branches were subsequently lost, considerable algal tissue would be removed: an average of $67 \%(\mathrm{SE}=2, \mathrm{n}=47)$ of thallus length (on that side of the thallus) would be lost by this process of slug feeding and tissue detachment. Based on these results, broken Codium stipes should be abundant in the field. In fact, in May 1992, ca $10 \%$ of the attacked and/or damaged fronds $<10 \mathrm{~cm}$ were actually stumps of algal stipes; in early June, the value had tripled.

Observations of tagged Codium demonstrated that branch loss was very rapid. For example, $75 \%$ of the 12 thalli tagged at Boiler Bay lost either branches or the

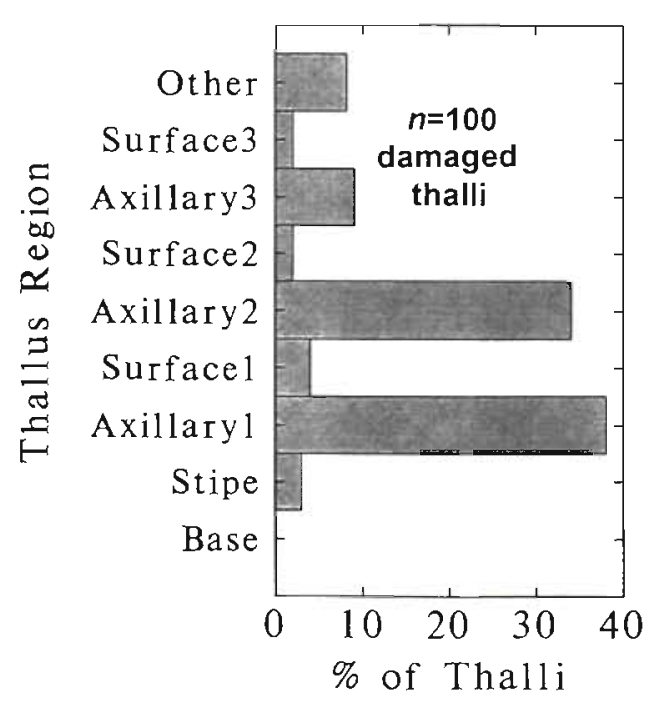

Fig. 4. Frequency that different regions of Codium fragile were the most proximal location of grazing damage by Placida dendritica in May 1992 at Boiler Bay 
entire thallus (except for the stipe and holdfast) in a $12 \mathrm{~d}$ period in early May 1989. In late May, $52 \%$ of 33 tagged thalli lost branches in $2 \mathrm{~d}$. Most thalli with weakened branches showed clear signs of grazing damage by Placida. The ascoglossan was associated with ca $82 \%$ of the stumps of newly lost branches in May 1992. Based on visual inspection in situ, the value undoubtedly was a conservative underestimate: microscopic examination presumably would increase the estimate.

Demonstrating experimentally that Placida induced branch loss, however, was problematic because of the small size and high mobility of the slugs. In 2 sea slug addition experiments, Codium branch loss did not vary significantly between control and experimental thalli (Fisher's exact tests, $p=0.273, n=12 ; p=0.732, n=33$ ) The lack of an effect may indicate that Placida (1) did not cause branch loss, (2) rapidly moved off experimental thalli, or (3) was so abundant on all host thalli that a treatment effect was masked. My observations support the latter 2 processes: added ascoglossans were not present on experimental thalli at the end of the experiments and ascoglossans occurred on most thalli on the shore. In the absence of an unambiguous experimental result, the most convincing evidence that Placida herbivory caused branch loss was visual examination of thalli in situ (Fig. 1)

\section{Seaweed and epiphyte attributes}

Placida occupied $70 \%$ of the 181 large Codium thalli (>10 cm) examined in spring and summer of 1987 and 1988. In May 1992, Placida was visible on ca $10 \%$ of
A.

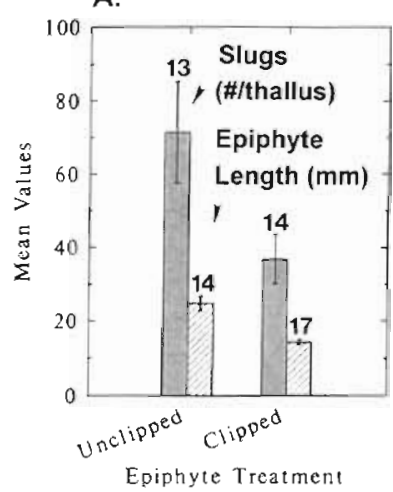

B.

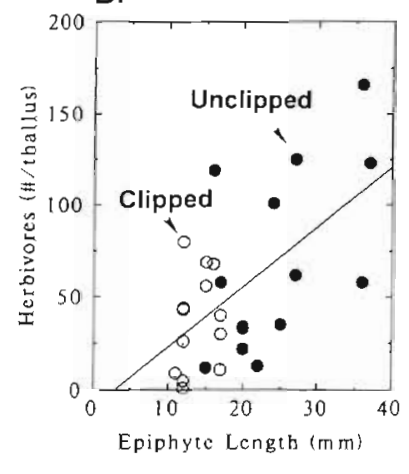

Fig. 5. (A) Abundance of Placida dendritica on Codium fragile in 2 treatment groups: clipped and unclipped epiphyte Ceramium codicola. Error bars denote $\pm 1 \mathrm{SE}$. Sample sizes indicate the number of replicate thalli in each treatment. (B) Relation between ascoglossan abundance and epiphyte length with 2 treatments pooled. Data were based on a 1 mo experiment conducted in April 1992 the small axes and ca $70 \%$ of the large ones (Fig. 3D). Large Codium were attacked more frequently than were small thalli (Fig. 3D, G-test, $G=153.5, \mathrm{df}=8, \mathrm{p}<$ $0.001, \mathrm{n}=612$ ), and algal hosts with Ceramium were attacked significantly more frequently than conspecifics without epiphytes $(G=131.9, \mathrm{df}=1, \mathrm{p}<0.001$, $\mathrm{n}=612)$.

In the field experiment, Placida was significantly more abundant on Codium with epiphytes than on conspecific thalli with clipped epiphytes (Fig. 5A, 1 tailed Student's t-test, $t=1.9,0.025<\mathrm{p}<0.05, \mathrm{n}=27$ ). The results were not due to between-treatment differences in Codium wet mass (Mann-Whitney, $U=135.0$, $\mathrm{p}=0.525, \mathrm{n}=31)$ or thallus length $(t=1.1, \mathrm{p}=0.281$, $\mathrm{n}=31)$. Epiphytes were significantly shorter in the clipped treatment than the unclipped control (Fig. 5A, $U=221.5, \mathrm{p}<0.001, \mathrm{n}=31$ ). Because the epiphytes were highly branched, the reduction in length due to clipping substantially reduced epiphyte biomass. When data from the 2 treatments were pooled, Placida abundance per thallus was directly related to maximum epiphyte length (Fig. 5B, 1-tailed Spearman rank correlation, $\mathrm{r}_{\mathrm{s}}=0.458, \mathrm{n}=27, \mathrm{p}<0.01$ ).

\section{Fine-scale patterns}

\section{Seaweed region}

The distribution of Placida on Codium thalli varied significantly with ascoglossan body size (Fig. 6A, Gtest, $G=28.0, \mathrm{df}=6, \mathrm{p}<0.001, \mathrm{n}=1301$ ) though the majority of slugs (of all sizes) occurred on axillary regions of branches and exposed surfaces (Fig. 6A). Of 726 groups examined in 1987 and 1988, 36\% were composed of 2 or more individuals.

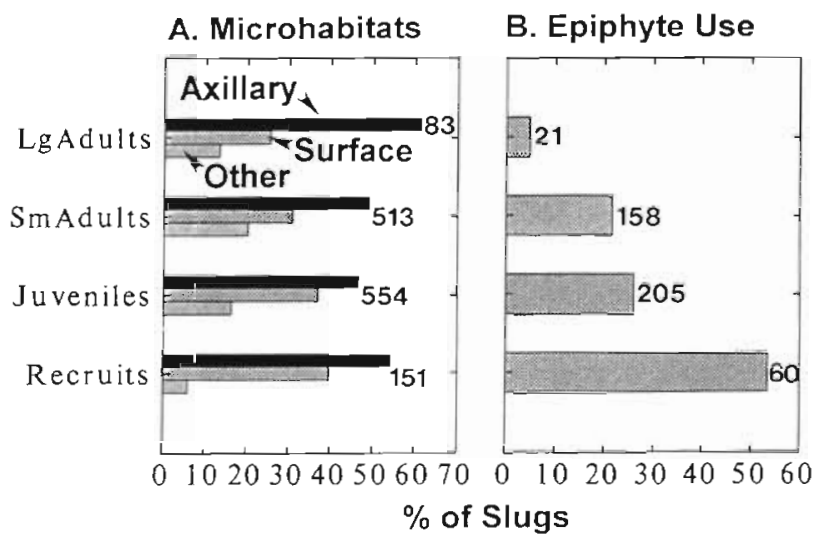

Fig. 6. Size-specific use of (A) thallus microhabitats and (B) epiphyte cover by Placida dendritica on Codium fragile freshly collected from Boiler Bay. Sample sizes indicate the number of ascoglossans in each size category. Data were pooled from all spring and summer censuses in 1987 and 1988 

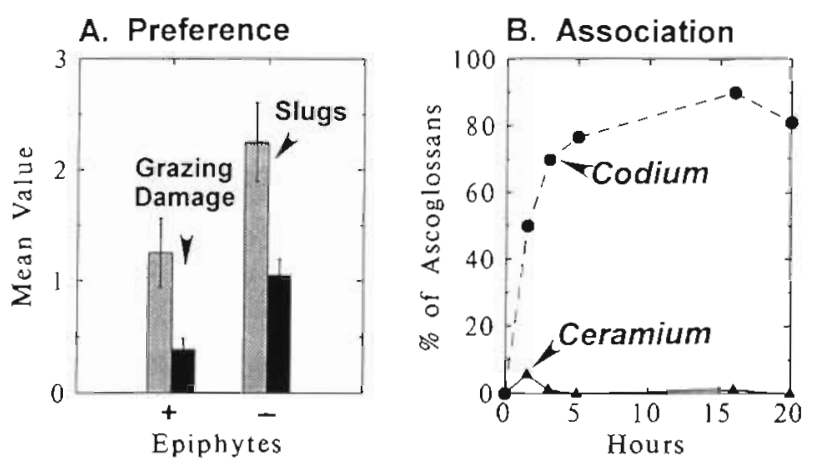

Fig. 7. (A) Abundance (no. thallus ${ }^{-1}$ ) of and relative grazing damage by adult Placida dendritica on Codium fragile with and without epiphytes in a laboratory choice experiment. Data are mean values ( $\pm 1 \mathrm{SE}$ ) of 28 containers of 5 slugs each. (B) Percentage of ascoglossans that associated with the seaweed host $C$. fragile and the epiphyte Ceramium codicola during a $1 \mathrm{~d}$, no-choice laboratory experiment. Data were pooled from 9 replicates per algal species with 10 ascoglossans per replicate

Epiphytes

The association of Placida with epiphyte cover decreased significantly with increased body size $(G$ test, $G=28.3$, df $=3, p<0.001, n=444$ ). For example, $>50 \%$ of recruits but only ca $5 \%$ of large adults on branch surfaces were under Ceramium cover (Fig. 6B). In the laboratory, adult Placida preferred Codium without Ceramium to host tissue with the epiphyte, based on slug abundance and grazing damage (Fig. 7A). Thus, epiphytes per se did not directly enhance the attractiveness of Codium as food.

Furthermore, Ceramium was not attractive to Placida (Fig. 7B), even in the absence of algal hosts. For example, 50 to $90 \%$ of the ascoglossans offered Codium were on the seaweed during each census; in contrast, $<6 \%$ of the ascoglossans offered Ceramium associated with the epiphyte. Although no quantitative data were collected, after $1 \mathrm{wk}$ ascoglossans held with Codium were green (from ingested algal chloroplasts) and had grown; conspecifics held with Ceramium were pale and small.

\section{DISCUSSION}

\section{Herbivore-seaweed interactions}

Herbivory by the ascoglossan Placida weakened branches, thus producing substantially more algal tissue loss than the amount consumed. Therefore, even low densities of ascoglossans can have ecologically important effects on macroalgal hosts. Comparable effects have been observed for Placida on Codium fragile subsp. tomentosoides (Clark 1975 and pers. comm.) and demonstrated for grazers associated with kelps: isopods burrowing into haptera, limpets weakening rachises, snails excavating holes in stipes and blades, and sea urchins biting through stipes (Fralick et al. 1974, Barrales \& Lobban 1975, Black 1976, Santelices \& Ojeda 1984, Dayton 1985, Johnson \& Mann 1986). Ascoglossans feeding on lower regions of filamentous green algae also appear to detach algal strands (Clark 1975, Trowbridge 1993).

Placida primarily removed older, heavier axes of Codium with epiphytes and not younger, shorter axes. Similarly, in kelp, older haptera were attacked more frequently than younger tissue (Barrales \& Lobban 1975). Because the larger axes probably exerted considerable hydrodynamic drag on Codium, their removal may enhance the survival of remaining fronds from the same holdfast. Black (1976) suggested that a similar type of pruning by limpets 'could have served the beneficial function of preventing an Egregia [kelp] from becoming so large that it was susceptible to detachment.'

This type of process may be most common for 2 different types of marine herbivores: (1) grazers restricted to the benthos (e.g., urchins, chitons) that feed on large seaweeds with a distinct stipe and (2) grazers that concentrate their attack on specific parts of algal hosts. Because many seaweeds have secondary metabolites that deter grazers (reviewed by Hay \& Fenical 1988) and because allocation patterns are often directly related to the presumed value of the thallus part (to the seaweed), herbivore feeding concentrated on structurally vital algal tissue would be expected in species that have circumvented algal chemical defenses: small herbivores such as amphipods and ascoglossans.

The consequence of extensive tissue loss to seaweed depends in part on the tissue's fate. Because most seaweeds probably cannot reattach to the substratum following dislodgment, removed tissue eventually senesces. Although uneaten Codium fragments may potentially reattach (Borden \& Stein 1969, Fralick \& Mathieson 1972), this phenomenon was never observed on the shore for $C$. fragile indigenous to the NE Pacific (C. D. Trowbridge pers. obs.).

\section{Herbivore-epiphyte interactions}

At least 6 processes may account for the enhanced abundance of Placida on Codium with the epiphytic Ceramium. (1) The epiphytic red alga may induce ascoglossan metamorphosis in a manner similar to that described for chitons and abalone (Barnes \& Gonor 1973, Morse et al. 1979, 1980, 1984, Morse \& 
Morse 1984). Although ascoglossans typically feed on green seaweeds (Greene 1970, Jensen 1980, 1981), molluscan metamorphosis may be conservative and, thus, be stimulated by non-food algae (e.g. epiphytic red algae). This hypothesis, however, is contrary to current views of many opisthobranch workers (reviewed by Hadfield \& Switzer-Dunlap 1984) though pertinent data for ascoglossans are too limited to evaluate.

Ceramium may enhance (2) settlement or (3) postsettlement survival of Placida by ameliorating environmental conditions. For example, the epiphyte may act as a baffle, reducing water velocity around Codium, enabling larvae to settle. Furthermore, the epiphyte may provide a cool, moist microhabitat during low-tide exposure. Desiccation may be more important for small slugs (because of their presumably higher ratio of surface area to mass) than for larger conspecifics. The ascoglossan's size-specific shift in association with epiphytes is consistent with this mechanism.

(4) Although the highly branched epiphyte may provide refuge to newly settled ascoglossans from predators, the importance of this role is not clear. Immature ascoglossans $(<1 \mathrm{mg})$ probably had a partial escape from predators due to their small size: either escaping detection or being too small for predators to consume. Yet, association with epiphytes decreased with increased slug size: most adult slugs were not associated with epiphytes (Fig. 6B), despite their greater visibility to predators.

(5) Algal utricles may be too thick for recently metamorphosed sea slugs to puncture: in the absence of feeding conspecifics, small Placida often die (Trowbridge 1991b). Ceramium may enhance the survival of recent recruits by providing the herbivore with access to the thin lateral walls of utricles: the epiphyte extends its rhizoidal holdfast into Codium thalli, loosening and separating the otherwise tightly packed utricles (C. D. Trowbridge pers. obs.). This type of facilitation may be less important for large ascoglossans.

(6) Herbivores may select macrophytes with epiphytes because epiphytism may be associated with physiologically stressed Codium. Stressed plant tissue is often, though not always, higher in food quality than unstressed tissue (White 1984, Renaud et al. 1990 and references therein). This stress mechanism probably did not occur in the Placida-Codium-Ceramium association because adult ascoglossans in the laboratory preferred host tissue without epiphytes (Fig. 7A) Furthermore, if ascoglossans preferred stressed thalli, Placida attack in the field experiment should not have differed between treatments (unless Codium condition changed upon epiphyte removal) because all thalli initially had epiphytes.
These processes are not mutually exclusive: enhanced abundances of Placida on epiphytized Codium hosts were probably due to several processes. For other herbivore-epiphyte associations, the enhanced settlement hypothesis (2) and amelioration hypothesis (3) seem most general for marine intertidal organisms on wave-swept shores.

Acknowledgements. I thank J. Lubchenco and B. Menge for their generous advice and support and L. Weber for the use of facilities at the Hatfield Marine Science Center. Discussions with $\mathrm{H}$. Ross improved the research. B. Menge, K. Clark, $\mathrm{R}$. Taylor, and 2 anonymous reviewers made valuable comments on earlier drafts of this manuscript. This research was supported by grants from Lerner-Gray Fund, American Museum of Natural History; Sigma Xi, The Scientific Research Society; Hawaiian Malacological Society; National Science Foundation grants OCE-8811369 to B. Menge and OCE-8600523 to J. Lubchenco and D. Carlson. The completion of the manuscript was supported by the Leigh Marine Laboratory, University of Auckland and National Science Foundation grant INT8888850 OR0 to the author.

\section{LITERATURE CITED}

Abbott, I. A., Hollenberg, G. J. (1976). Marine algae of California. Stanford University Press, Stanford, CA

Barnes, J. R., Gonor, J. J. (1973). The larval settling response of the lined chiton Tonicella lineata. Mar. Biol. 20:259-264

Barrales, H. L., Lobban, C. S. (1975). The comparative ecology of Macrocystis pyrifera, with emphasis on the forests of Chubut, Argentina. J. Ecol. 63: 657-677

Black, R. (1976). The effects of grazing by the limpet, Acmaea insessa, on the kelp, Egregia laevigata, in the intertidal zone. Ecology 57: 265-277

Borden, C. A., Stein, J. R. (1969). Reproduction and early development in Codium fragile (Suringar) Hariot: Chlorophyceae. Phycologia 8: 91-99

Brandley, B. K. (1984). Aspects of the ecology and physiology of Elysia cf. furvacauda (Mollusca: Sacoglossa). Bull. mar. Sci. 34: 207-219

Brawley, S. H., Adey, W. H. (1981). The effect of micrograzers on algal community structure in a coral reef microcosm. Mar. Biol. 61: 167-177

Brawley, S. H., Fei, X. G. (1987). Studies of mesoherbivory in aquaria and in an unbarricaded mariculture farm on the Chinese coast. J. Phycol. 23: 614-623

Brönmark, C. (1985). Interactions between macrophytes, epiphytes and herbivores: an experimental approach. Oikos 45: $26-30$

Brönmark, C. (1989). Interactions between epiphytes, macrophytes and freshwater snails: a review. J. mollusc. Stud. 55: $299-311$

Brostoff, W. N. (1988). Seaweed community structure and productivity: the role of mesograzers. Proc. 6th int. Coral Reef Symp. 2: 1-6

Buschmann, A. H., Bravo, A. (1990). Intertidal amphipods as potential dispersal agents of carpospores of Iridaea laminarioides (Gigartinales, Rhodophyta). J. Phycol. 26: $417-420$

Buschmann, A. H., Santelices, B. (1987). Micrograzers and spore release in Iridaea laminarioides Bory (Rhodophyta: Gigartinales). J. exp. mar. Biol. Ecol. 108: 71-79 
Caine, E. A. (1980). Ecology of two littoral species of caprellid amphipods (Crustacea) from Washington, USA. Mar. Biol 56: $327-335$

Cattaneo, A. (1983). Grazing on epiphytes. Limnol. Oceanogr 28: $124-132$

Clark, K. B. (1975). Nudibranch life cycles in the Northwest Atlantic and their relationship to the ecology of fouling communities. Helgoländer wiss. Meeresunters. 27: 28-69

Coen, L. D. (1988a). Herbivory by Caribbean majıd crabs: feeding ecology and plant susceptibility. J. exp. mar. Biol. Ecol. 122: 257-276

Coen, L. D. (1988b). Herbivory by crabs and the control of algal epibionts on Caribbean host corals. Oecologia 75: $198-203$

D'Antonio, C. (1985). Epiphytes on the rocky intertidal red aiga Rhodomela larix (Turner) C. Agardh: negative effects on the host and food for herbivores? J. exp. mar. Biol. Ecol. 86: $197-218$

Dayton, P. K. (1985). Ecology of kelp communities. A. Rev. Ecol. Syst. 16: 215-245

Dudley, T. L. (1992). Beneficial effects of herbivores on stream macroalgae via epiphyte removal. Oikos 65: 121-127

Duffy, J. E. (1990). Amphipods on seaweeds: partners or pests? Oecologia 83: 267-276

Fralick, R. A., Mathieson, A. C. (1972). Winter fragmentation of Codium fragile (Suringar) Hariot ssp. tomentosoides (van Goor) Silva (Chlorophyceae, Siphonales) in New England. Phycologia 11: 67-70

Fralick, R. A., Turgeon, K. W., Mathieson, A. C. (1974). Destruction of kelp populations by Lacuna vincta (Montagu). Nautilus 88: 112-114

Goff, L. J., Liddle, L., Silva, P. C., Voytek, M., Coleman, A. W. (1992). Tracing species invasion in Codium, a siphonous green alga, using molecular tools. Am. J. Bot. 79: $1279-1285$

Greene, R. W. (1970) Symbiosis in sacoglossan opisthobranchs: symbiosis with algal chloroplasts. Malacologia 10: $357-368$

Hadfield, M. G., Switzer-Dunlap, M. (1984). Opisthobranchs. In: Tompa, A. S., Verdonk, N. H., van den Biggelaar, J. A. M. (eds.) The Mollusca, Vol. 7, Reproduction. Academic Press, New York, p. 209-350

Hay, M. E., Fenical, W. (1988). Marine plant-herbivore interactions: the ecology of chemical defense. A. Rev. Ecol. Syst. 19: 111-145

Howard, R. K. (1982). Impact of feeding activities of epibenthic amphipods on surface-fouling of eelgrass leaves. Aquat. Bot. 14: 91-97

Jensen, K. R. (1980). A review of sacoglossan diets, with comparative notes on radular and buccal anatomy. Malacol. Rev. 13: 55-57

Jensen, K. R. (1981). Observations on feeding methods in some Florida ascoglossans. J. mollusc. Stud. 47: $190-199$

Johnson, C. R., Mann, K. H. (1986). The importance of plant defence abilities to the structure of subtidal seaweed communities: the kelp Laminaria longicruris de la Pylaie survives grazing by the snail Lacuna vincta (Montagu) at high population densities. J. exp. mar. Biol. Ecol. 97: 231-267

Kitting, C. L. (1989). Algal recruitment among dense invertebrate herbivores; do intertidal molluscan 'grazers' enhance their algal foods. Bull. mar. Sci. 45: 550

Lobel, P. S., Ogden, J. C. (1981). Foraging by the herbivorous parrotfish Sparisoma radians. Mar. Biol. 64: 173-183

Mazzella, L., Russo, G. F. (1989). Grazing effect of two Gibbula species (Mollusca, Archaeogastropoda) on the epi- phytic community of Posidonia oceanica leaves. Aquat. Bot. 35: $357-373$

Morse, A. N. C., Froyd, C., Morse, D. E. (1984). Molecules from cyanobacteria and red algae that induce larval settlement and metamorphosis in the mollusc Haliotis rufescens. Mar. Biol. 81.293-298

Morse, A. N. C., Morse, D. E. (1984). Recruitment and metamorphosis of Haliotis larvae induced by molecules uniquely available at the surfaces of crustose red algae. J. exp. Mar. Biol Ecol. 75: 191-215

Morse, D. E., Duncan, H., Hooker, N., Baloun, Young, G. (1980). GABA induces behavioral and developmental metamorphosis in planktonic molluscan larvae. Fed. Proc. 39: $3237-3241$

Morse, D. E., Hooker, N., Duncan, H., Jensen, L. (1979). $\gamma$-Aminobutyric acid, a neurotransmitter, induces planktonic abalone larvae to settle and begin metamorphosis. Science 204: 407-410

Nicotri, M. E. (1977). The impact of crustacean herbivores on cultured seaweed populations. Aquaculture 12: 127-136

Nicotri, M. E. (1980). Factors involved in herbivore food preference. J. exp. mar. Biol. Ecol. 42: 13-26

Norton, T. A., Benson, M. R. (1983). Ecological interactions between the brown seaweed Sargassum muticum and its associated fauna. Mar. Biol. 75: 169-177

Renaud, P. E., Hay, M. E., Schmitt, T. M. (1990). Interactions of plant stress and herbivory: intraspecific variation in the susceptibility of a palatable versus an unpalatable seaweed to sea urchin grazing. Oecologia 82: 217-226

Robertson, A. I., Mann, K. H. (1982). Population dynamics and life history adaptations of Littorana neglecta Bean in an eelgrass meadow (Zostera marina L.) in Nova Scotia. J. exp. mar. Biol. Ecol. 63: 151-171

Santelices, B., Ojeda, F. P. (1984). Population dynamics of coastal forests of Macrocystis pyrifera in Puerto Toro, Isla Navarino, Southern Chile. Mar. Ecol. Prog. Ser. 14: $175-183$

Scagel, R. F., Garbary, D. J., Golden, L., Hawkes, M. W (1986). A synopsis of the benthic marine algae of British Columbia, northern Washington and southeast Alaska Phycological Contribution 1, Department of Botany, University of British Columbia, Vancouver

Schmekel, L., Portmann, A. (1982). Opisthobranchia des Mittelmeers, Nudibranchia und Saccoglossa. SpringerVerlag, Berlin

Shacklock, P. F., Croft, G. B. (1981). Effect of grazers on Chondrus crispus in culture. Aquaculture 22: 331-342

Shacklock, P. F., Doyle, R. W. (1983). Control of epiphytes in seaweed cultures using grazers. Aquaculture 31: 141-151

Trowbridge, C. D. (1991a). Diet specialization limits herbivorous sea slug's capacity to switch among food species. Ecology 72: 1880-1888

Trowbridge, C. D. (1991b). Group membership facilitates feeding of the herbivorous sea slug Placida dendritica. Ecology 72: 2193-2203

Trowbridge, C. D. (1992a). Mesoherbivory: the ascoglossan sea slug Placida dendritica may contribute to the restricted distribution of its algal host. Mar. Ecol. Prog. Ser. 83: $207-220$

Trowbridge, C. D. (1992b). Phenology and demography of a marine specialist herbivore: Placida dendritica (Gastropoda: Opisthobranchia) on the central coast of Oregon. Mar. Biol. 114: 443-452

Trowbridge, C. D. (1993). Feeding ecology of the ascoglossan opisthobranch Aplysiopsis enteromorphae (Cockerell \& Eliot): patterns of distribution and impact on tidepooldwelling green algae. J. exp. mar. Biol. Ecol. 169: 233-257 
Van Montfrans, J., Orth, R. J., Vay, S. A. (1982). Preliminary studies of grazing by Bittium varium on eelgrass periphyton. Aquat. Bot. 14: 75-89

This article was presented by J. Nybakken, Moss Landing, California, USA
White, T. C. R. (1984). The abundance of invertebrate herbivores in relation to the availability of nitrogen in stressed food plants. Oecologia 63: 90-105

Manuscript first received: August 3, 1992 Revised version accepted: June 28, 1993 